\title{
LIII. Essay on agriculture, as a science, subdivided into separate departments
}

\section{W. Richardson D.D.}

To cite this article: W. Richardson D.D. (1816) LIII. Essay on agriculture, as a science, subdivided into separate departments, Philosophical Magazine Series 1, 48:222, 262-270, DOI: $10.1080 / 14786441608637660$

To link to this article: http://dx.doi.org/10.1080/14786441608637660

册 Published online: 27 Jul 2009.

Submit your article to this journal

Џ Article views: 2

Q View related articles $₫$ 
manner, those parts of my papers which have been thought censurable by Mr. De Luc, I cannot omit acknowledging the gratification I have derived from his approbation of the other parts; and the more particularly as his principal objections to iny statements, those which he thinks supported by his own experiments, appear to me to have arisen from his having misunderstood the purport of what I have written. I beg leave. to express the very high consideration and respect I have for him, and

$$
\begin{aligned}
& \text { I am, sir, } \\
& \text { Your obliged and faithful servant, } \\
& \text { J. D. MAYcock, M.D. }
\end{aligned}
$$

LIII. Essay on Agriculture, as a Science, subdivided into separate Departments. By W. Richardoson, D.D.

I HAve often lamented that agriculture, far from being considered as a science, and treated as such, was reduced merely to a measure of practice, and left in the hands of persons little qualified to advance the theoretical knowledge of this useful branch of learning, and little disposed to improve its practice, by changing the usages to which they were most obstinately attached, or even to admit that their practices were capable of receiving improvement.

This earliest, and most necessary of all sciences, ought, as I think, to be considered as consisting of three separate departments, distinct from each other; the theoretical-the experimental-and the practical.

The first and second are at present quite absorbed by the third, without any prospect of emerging in their proper and distinct characters.

I shall endeavour to describe the qualities which I conceive the dormant personages representing these several departments ought to possess, and their respective offices.

The theorist should be well acquainted with natural history in general, as well as with that of the several vegetables we are used to cultivate for our own consumption or that of our domestic animals; - their habits, their properties-their seasons of attaining perfection.- He watehes the process of Nature with attention, and combines his general observations with those he has made on the particularities of each separate vegetable, and then spectlates, a priori, on the modes of culture best suited to them; and the soils best adapted to them, and likely to make them bring forward their produce in the greatest abundance and highest perfection.

Are the suggestions of the theorist to be immediately adopted and 
and carried into practice? By no means;-they must undergo the test of experiment. Here the second department of the agricultural school, as arranged by me, opens, and a new personage is introduced.

The experimentalist should be careful, patient, and diligent, without prejudices or even opinions on the subjects before him : he is to make his experiments on the very smallest scale, so that he can diversify them without expense, and without having any interest in their success,-failure is to him exactly the same thing; as information is his sole object.

This personage adopts the ideas, and if you please the whims of the theorist, which he is not to presume to call Utopian-he gives them a fair and patient trial under clifferent circumstances, and on a small scale. Shall he discover any thing, in the slightest degree promising, he repeats, and varies his experiments, until he satisfes himself, either that the measure is a vain one, or that it deserves attention. In this latter case the experimentalist makes his report to the agriculturists, recommends to them to try the measure on a larger scale, and in actual practice.

Even expense, ultimately so important, is not in an early stage to stop proceedings; for the object immediately before the school is to devise by what means the vegetable in their hands can be brought to the highest degree of perfection and utility; - the question of expense comes next ; this on his diminutive scale, is nothing to the experimentalist,-but should it threaten to be weighty, the ingenuity of all parties is now to be exerted to find suecedanea; and a knowledge of the subject being acquired, measures may be devised which will attain the object by more accessible means.

The third character in the drama is the practical agriculturist, of whom I complain that he has taken upon himself the whole three characters I mentioned: He treats the theorist with supercilious contempt, as presuming to obtrude his wild speculations into a department of which he considers hirrself as complete master.

Hence improvements are discouraged, and discoveries that might have proved useful are nipped in the bud.

The second character I wish to introduce does not yet exist; whence it comes that discoveries which have been forced into attention rarely meet with a fair trial : they are encoustered by the practical farmer with prejudice, and even with jealousy; they are considered as obtrusions; and treated as uninvited, unwelcome strangers.

It is some thirty years since Dr. Lettsom brought mangel wurzel to England, and was strenuous in his exertions to teach the 
use and value of that excellent root : yet the English agriculturists, though so fond of house feeding, let it slip through their fingers: and if, after a lapse of many years, they have at last become sensible of its value, it was owing to the strenuous interference of my amiable countrywoman, the marchioness of Salisbury: it is, at least, to this noble agriculturist that we owe the introduction of this important vegetable into Ireland; and I am proud of having been an active instrument under her ladyship, who was so good as for years to supply me with seed.

Sometimes, indeed, the practical farmer persuades himself that he has assumed the character of the experimentalist, and tells us he has made the experiment;-that is, he has cultivated a field in a particular way. But it is not from solitary trials on a great scale that information is to be obtained; experiments lead us to knowledge by comparison, - they should be multiplied and diversified.

Hence agriculture, as a science, is at a stand;-the present possessor of the field, perfectly satisfied with his own attainments, and in high admiration of his own practices (often very good), does not admit improvement to be necessary, and indignantly rejects any innovation.

He is encouraged in his contempt for theoretical speculations, by the ridicule which a witty author throws on the agricultural projectors of his day.

It is just a century since Swift made a bitter attack on the Royal Society, which he describes as a set of projectors, lately incorporated by royal patent.

It is not for me to defend this respectable body: a century has intervened since this wanton attack was made upon them, and their merits or demerits are best appreciated by their intermediate proceedings and transactions.

My olject in referring to the passage in Swif's Laputa, is to throw light on the arrangement $I$ have made in the agricultural science, and to afford proof of its propriety.

Swift says, "the professors contrive new rules and methods of agriculture-new instruments and tools; all the fruits of the earth shall come to maturity, at whatever season we think fit to choose, and increase an hundred-fold more than they do at present."

He states " the result of all this to be, that none of these projects are yet brought to perfection, and in the meantime the whole country lies miserably waste; by all which, instead of being discouraged, they are fifty times more bent on prosecuting their schemes."

Admitting this to be a fair aecount of the facts in Swift's day, 
(which I much doubt,) the picture he draws is a necessary result of his own statements, from which we can infer,

That in his time projectors were wild and speculative-practical agriculturists not quite so averse from innovations as at present, but equally tenacious of their practices when once adopted.

The whole mischief (admitting it to have existed) obviously arose from Swift's having omitted a personage in the agricultural drama, forming a coalition between the wild theorist and positive practical farmer; omitting the intermediate personage, the experimentalist, who would have protected them both from mischief, suppressing the extravagancies of the projector, and paying every attention to his suggestions that bore the test of experiment; and suffering nothing to pass into practice, which did not afford a reasenable prospect of advancing the agricultural science, and multiplying the benefits derived from it.

Let us try two or three agricultural questions by the test of the arrangement $I$ have suggested, and we shall see what progress the science has made without them, and to what state it probably would have advanced, had they been adopted.

I commenee with the gramina, a branch of agriculture to which for twenty years I have paid considerable attention, and which, for these last ten, I have considered as my peculiar department.

The great importance to us of grassy produce is obvious; and nature has been very liberal to us in that line-she has given us (as botanists tell us) one hundred and fifty varieties to supply the wants of our cattle, and to exercise our ingenuity in discovering their uses and developing their properties.

What use has the agriculturist derived from this copious stock? But a solitary one.-He has discovered that rye grass when sown with clover makes an excellent mixture; into further practice his knowledge does not carry him: and yet in dogged confidence he turns a deaf ear to any suggestions for increasing his stock of grasses, or advancing his knowledge on their subject.

What would probably have been the result, had agriculture been distributed into the three departments I have supposed, and the gramina had passed through the hands of the theorist and experimentalist, before they reached the practical farmer?

The theorist, speculating a priori, wonld have considered what were the properties most likely to give value to grass, and by which it would be made most useful to our cattle: he would soon have perceived that three were prominent-earliness-luxuriance-and quick powers of reproduction after being cut or eaten down; he would have desired the experimentalist to make many small plots, and to compare the different grasses in these several points of view. 
The experimentalist would soon have discovered that the grasses possessing all, or the majority of these valuable qualities, were very few in number, and that rye-grass was not among them.

When I cease to generalize, I shall give a small essay on the grasses worth cultivation, having ascertained their comparative values, after nuch pains, and with great accuracy.

The miserable ignorance of the practical agriculturists on the subject of the gramina is easily accounted for ; they have consigned the task of instructing them on all rural subjects to two descriptions of persons-the Grub-street writers, who, withont ever having cultivated or perhaps secn a farm, maintain thenselves by furnishing agricultural magazines and newspapers with essays on such subjects as their employers point out, conceiving them to be popular at the time.

The second description of public instructors in the agricultural line are, the seed- and nursery-men, who, having their goods to dispose of, take the opportunity of displaying their own great knowledge, and of puffing their saleable commodities; these gentry often publish agricultural volumes, which they find a very lucrative trade, as the English buy every thing in that line, conceiving they are purchasing information.

The ignorance of these charlatans is scarcely credible, nor is it easy to tell to what mischief it may have led ; both the seedsmen and the books of their predecessors have recipes, nostrums, stating mixtures of eight or nine different species of grass, which they advise agriculturists to throw together in certain proportions of the seeds, and then to sow one mixture for meadow, another for pasture.

An examination of these lists by any one who understands the natural history and qualities of the several grasses, will instantly discover the mischievous ignorance of these quacks.

I should not have spoken so boldly on this subject, had I not evidence under the hands of the first seeds-men in London to confirm what I say.-It is common for improving gentlemen to desire their seeds-men to send them such a mixture of grass seed as will suit their soil. The order is instintly complied with, and the list established by the bill. I answer for it, whoever consults his bill for this list, will find many worthless grasses, of incompatible periods; and that he will find tall oat grass, avena elatior, recommended, and sent to him.

Now tall oat grass is by far the most mischievous of the squitch tribe; it has small bulbous roots like the crocus, and is known in this country by the names of purl grass and knot squitch; it is reprobated by our farmers as one of our most troublesome weeds.

Such is the style of instruetion we receive from the present agricultural 
agricultural authorities; and so long as that task is left in such unhappy hands, it is no wonder that our knowledge of any particular branch of this useful science should be sadly limited; or that Sir Humphry Davy should complain, that our acquaintance with the gramina should be confined to two species*.

Better prospects are now opening; a revolution has fortunately taken place;-philosophy supported by science has stepped forward, and the Board of Agriculture, with its able chemical lecturer, have rescued the gramina at least from the hands of mercenary ignorance.

This unexpected irruption of science into the peaceful and productive domain of these indefatigable scribblers has excited no small uneasiness in Grub-street; one of the gentlemen, whose name is perpetually occurring in almost every agricultural publication, shows the alarm that school has taken, at the dangerous invasion of their territories. He says:

"I am far from wishing to depreciate the use of science, as directed to the improvement of agriculture; but the pleasure, the delight there is in studying Nature through these spectacles, is greater than its benefit."

"A All that science has done to improve our knowledge of the value of the grasses as yet, consists in showing which affords the greater proportion of saccharum:-with those who sing the praises of analysis, the burthen of the song is saccharum."

"Can it be reasonably said that the choice of rye-grass, as a separate grass, was the result of accident? This text that is quoted from Sir Humphry Davy is not Gospel." Again.

"This account is miserable, because it is not true; and the hasty expressions of great men ought to be more carefully repressed, as they are the more widely diffused."

I know not any question in rural practice that more requires the interference of the scientific theorist than the proper period for mowing, nor any point upon which the practical farmer is more ignorant or more opinionated-he prides himself on having saved his hay before others, and boasts of its fragrance and tealike verdure.

The theorist, acquainted with natural history, would have told him that the juices of all vegetables attain their greatest per-

* Sir Humphry Davy admits two varieties to be in use ; but the second, cocksfoot, is a recent introduction; and the first recommendation of this. luxuriant grass to the practical farmer, will be found in the Transactions of the Royal Irish Academy, six or seven years ago, in a memoir of mine, on the useful grasses, with my reasons for strongly reconmending cocksfoot, deduced from its natural history.

Whoever has published any earlier recommendation of this grass to the agriculturists of his country, is entitled to the credit of its intraduction. 
fection in their inflorescence-that it is at this period alone all extracts from vegetable substances are taken: and as in the case of hay the whole vegetable is preserved, it is of great importance that it should be mowed in its highest state of perfection, that is, when the predominant varieties of grass are in flower.

The practical farmer knows nothing of all this: he has his own rules for deciding on maturity, and generally cuts his crop before either the cocksfoot or the rye-grass (the two earliest of our predominant grasses) are in flower.

I sometimes feel an ill-natured pleasure when I see the trampcocks of these early gentry collapse considerably for want of substance, giving evidence of premature mowing, and establishing the inferiority of the hay.

Here the experimentalist would be useful, by enabling us to compare portions of hay from the same crop, cut at different periods-even the farmer himself, would he condescend to doubt, might soon satisfy himself: by leaving the amount of a trampcock uncut for one, two, or perhaps three weeks, later than the rest, he would probably find his hay firmer and better; he is certain also, the quantity is somewhat increased.

Was the arrangement $I$ recommend adopted, many agricultural questions of much importance would receive speedy solutions.That of the proper seasons for sowing our several grains has been much agitated.

Upon this question the theorist would pronounce generally, that agricultural policy directed the season for sowing each vegetable, to be so chosen, that it might remain above ground in the very best portion of the year, neither exposed unnecessarily to late frosts in its tender state, nor to premature winter severities when ripening its seed.

Hence the season for sowing each vegetable should be determined by the interval between the seed and the sickle, which Nature has assigned to each species, corresponding with the period of gestation in animals, and unalterably fixed at the time of their original formation. Upon this principle it is obvious that the vegetables of slowest growth should be sown first, while those of quicker progress should be delayed longer.

The question has now reached the experimentalist, who will probably sow many varieties in distinct plots, on the same day; and by accurately observing their times of ripening will make himself acquainted with their respective periods.

What $I$ recommend here as experiment, is the actual' practice in Egypt, where they sow all their grains, of whatever species, on the same day, that is, the first moment the retreat of the Nile gives them access to their land, just relieved from its annual inundation. 
We have Scriptural authority for the result, marking the progress each separate grain had made in the same time.

Moses tells us that at the time of a particular event, "the harley was in the ear, and the flax was bolled, but the wheat and the rye were not grown up."

The experimentalist will now diversify his trials; and by sowing the saine grain at different times, in many sinall plots, he will soon be able to determine, how far, for the security of the young tendril, he can delay sowing, without throwing the mature plant into a season unfit for ripening its seed.

It has been made a question-Whether in choosing our corn for seed, we should choose our weightiest pickle, or whether the smaller and lighter might rot answer just as well ;-in other words: From which side of our winnowing heap are we to take our seed-the windward-or the leeward? The fuller, plumper and larger grain, will not cover so much ground as the smaller, and is also of higher price; hence by sowing the smaller and lighter grain, we should save considerably; and Sir Joseph banks is of opinion we may safely take our seed from the leeward side of the heap.

Was the question brought before the agricultural school, arranged as I suppose ; - the theorist would tell us that the farina constitutes the whole value of the corn; that this portion of the vegetable forms no part of the organic construction, has no connexion with the vital principle of the germ, hut is merely a mass of unorganized matter, provided by Nature for the sustenance of the nascent plant, until by its roots it can extract food for itself; - - that the farina in vegetables corresponds with the yolk of the egg in oviparous animals.

Now we observe that in every thing connected with the preservation of species, Nature is not only liberal, but generally profuse, and (no doubt to provide against dificulties) often redtundant_-besides, the provision was made when the vegetable tribe was left to propagate itself, without any of the facilities devised by man, which he now gives to assist vegetation and increase produce.

More farina, it is obvious, would be required under the hardships of a state of nature ; and a grcater quantity will be formed uncler cultivation, as animals fostered by man acquire a degree af obesity which they never reach in a state of, nature. Thus it appears, the quantity of farina is increased, and the expenditure of it dirinished; of course it is highly probable, we may with safety avail ourselves of the redundance; that is, sow the lighter, and consume the weightier grain.

The question is now brought before the experimentalist, and one of the lightest he has to encounter; he need only sow a few 
small plots with seeds taken from the opposite sides of the winnowing heap, and by a careful comparative view of the crops when ripe, he will be able to pronounce upon the safety of the measure, and by attention he will soon discover what he will gain by pursuing it.

The preservation of the vigour of our soils, and the reparation of the waste they sustain by our perpetual call upon them for crops, and consequent loosening of their texture, by over frequent cultivation, is a subject of vast importance, and has already excited much attention.

The mechanical mole is simple; to renovate, and consolidate our harassed and open soil, by mixtures of firmer materials; that is, compost formed of strong earth, or pure clay well attenuated : but in loose, light and sandy ground, such consolidating materials are rarely found: the agriculturist is therefore thrown upon his own ingenuity; and I know not any instance in which it has been more successfully exerted.

He has found, that by alternating what are known to be exhausting crops, with those that are deemed to be melioratingculmiferous with root crops-farinaceous with green crops-he has brought his ground to bear more constant pressure than it was supposed capable of sustaining :- still the exhaustion, though much abated, is evidently perceivable, and the Norfolk farmers complain their grounds are tiring of their favourite turnip.

Mr. Gregg, now become very eminent as a practical agriculturist, admits rest to be indispensably necessary, and recommends two successive crops of grass.

To make that rest as effective as possible, let us speculate $a$ priori-Which are the grass crops that exhaust the ground least? Which are those that will consolidate and renovate it most effectually? And which, during the period of rest, will yield the greatest produce?

As the question is now brought within my own immediate department; when I cease to generalize, I shall on my return to the gramina, point out those, which I conceive best suited to these purposes, with my reasons, and shall then leave the question in the hands of the experimentalist.

It is in adversity, when the vegetables he is cultivating are attacked by various disorders, that the agriculturist will find the benefit of the arrangement I have suggested; as it will enable him to meet with strength, and I may say, discipline, the difficulties he will have to encounter.

But this subject must be reserved for another letter. Clonfecle, Moy, May 31, 1816.

W. Richardson, D.D. 